\title{
Enteric pathogen co-infections in the paediatric population from rural communities in the Vhembe District, South Africa
}

\author{
S E Ledwaba, ${ }^{1} \mathrm{MSc} ; \mathrm{J}$ P Kabue, ${ }^{1} \mathrm{PhD} ; \mathrm{T}$ G Barnard, ${ }^{2} \mathrm{PhD} ; \mathrm{A}$ N Traore, ${ }^{1} \mathrm{PhD} ; \mathrm{N}$ Potgieter, ${ }^{3} \mathrm{PhD}$ \\ ${ }^{1}$ Department of Microbiology, School of Mathematical and Natural Sciences, University of Venda, Thohoyandou, Limpopo Province, South Africa \\ ${ }^{2}$ Water and Health Research Unit, University of Johannesburg, Gauteng Province, South Africa \\ ${ }^{3}$ School of Mathematical and Natural Sciences, University of Venda, Thohoyandou, Limpopo Province, South Africa
}

\begin{abstract}
Background. Enteric pathogens co-infections are a serious health risk in children under the age of 5 years.
Objective. The study aimed to determine the prevalence of diarrhoea-causing pathogens in children suffering from diarrhoea in rural communities of the Vhembe District.

Methods. A cross-sectional study was conducted from July 2014 to June 2015. Diarrhoeal stool specimens ( N=237) were collected from children attending primary healthcare facilities in rural communities of the Vhembe District. Stools were screened for enteric viral adenovirus 40/41, rotavirus and norovirus pathogens by means of enzyme immuno-assay (EIA) and enteric bacterial Escherichia coli spp (diarrhoeagenic pathotypes), Shigella spp., Salmonella spp. and Vibrio spp. pathogens by means of multiplex polymerase chain reaction. Results. A total of 59.1\% (140/237) were positive for at least one or more enteric pathogens. Enterotoxigenic E. coli (ETEC) (27.9\%), enteroaggregative E. coli (EAEC) (26.8\%) and atypical enteropathogenic E. coli (EPEC) (17.9\%) were frequently detected in children less than 2 years of age. Bacterial-bacteria co-infections were detected in $24.5 \%(n=58)$ and bacterial-viral co-infections in $14.3 \%(n=34)$ of the stool specimens.

Conclusion. The findings indicated that enteric pathogen co-infections are major causes of diarrhoea in children less than 2 years of age in the Vhembe District.
\end{abstract}

S Afr J Child Health 2018;12(4):170-174. DOI:10.7196/SAJCH.2018.v12.i4.1550

Gastroenteritis in children is a major global problem. ${ }^{[1]}$ In subSaharan Africa, children are 15 times more likely to die from diarrhoeal diseases before the age of 5 years than children living in developed countries. ${ }^{[2]}$ The Vhembe District in Limpopo Province, South Africa, consists mostly of rural communities that still lack access to clean drinking water and proper sanitation. ${ }^{[3]}$ Some people living in these rural communities rely mainly on open water sources such as rivers as their source of drinking water, posing a serious health risk to young children. ${ }^{[3-5]}$

Diarrhoeal diseases are caused by various bacterial, parasitic and viral pathogens. Among these, diarrhoeagenic Escherichia coli (DEC) are frequently recognised enteric pathogens in children throughout the world. ${ }^{[6-10]}$ DEC pathotypes co-infections with other enteric pathogens are increasingly detected in children less than 5 years of age. ${ }^{[11-14]}$ Studies suggest that co-infections might result in increased clinical complications in infected children. In rural communities of the Vhembe District, few studies have been conducted on the prevalence of diarrhoeal pathogens in children..$^{[4,5,15-18]}$ Consequently, data on the prevalence of co-infections have not been documented in these settings, which could be due to cost and the long waiting period for data analysis before treatment starts. The aim of the present study was to determine the prevalence of co-infections of diarrhoeacausing pathogens in children in rural communities of the Vhembe District, South Africa.

\section{Materials and methods}

\section{Setting, collection of stool samples and study design}

This prospective cross-sectional study was carried out in rural communities of the Vhembe District in Limpopo Province, in the northern part of South Africa. Ethical clearance was obtained from the University of Venda (Ref: SMNS/12/MBY/0212) and the
Department of Health (Ref: 4/2/2). Informed and signed consent forms were obtained from participating parents and/or primary caretakers before collection of stools.

Between July 2014 and June 2015, 237 diarrhoeal stool samples from children under the age of 5 years were collected from primary healthcare facilities in the Vhembe District. Diarrhoea was defined as the passage of $\geq 3$ loose stools within 24 hours.

A standard questionnaire was used to record demographic and clinical data of each study participant. Samples were collected by a qualified nurse using a sterile stool container. The specimens were then kept at $-20^{\circ} \mathrm{C}$ until further analysis.

\section{Bacterial analysis}

Genomic DNA was extracted from all stool specimens using the QIAamp Fast DNA stool mini kit according to the manufacturer's instructions (Qiagen, Germany). Three published multiplex-PCR (m-PCR) protocols were used in this study.

A m-PCR protocol was used to indicate the presence of $E$. coli, Salmonella spp., Shigella spp., and Vibrio spp. as previously described. ${ }^{[19]}$ Briefly: the polymerase chain reaction (PCR) was performed in a total volume of $20 \mu \mathrm{L}$ containing 1 X QIAGEN multiplex PCR master mix (Qiagen, Germany) and consisted of 100 pmol of each primer, $2 \mu \mathrm{L}$ of the DNA template, and PCR-grade water.

Samples that tested positive for E. coli were further analysed using the 11-gene m-PCR as described previously ${ }^{[20]}$ to detect diarrhoeagenic E. coli (DEC) pathotypes, namely: enteroaggregative E. coli (EAEC), enteropathogenic E. coli (EPEC), enteroinvasive E. coli (EIEC), enterotoxigenic E. coli (ETEC) and enterohaemorrhagic E. coli (EHEC) ${ }^{[20]}$ Each reaction consisted of $1 \mathrm{X}$ Qiagen PCR multiplex mix (containing HotstartTaq DNA polymerase, m-PCR buffer and dNTP mix) (Qiagen, USA); $2 \mu \mathrm{L}$ of the primer mixture, 
$2 \mu \mathrm{L}$ of the DNA sample, $1 \mu \mathrm{L}$ of gapdh (external control) and $5 \mu \mathrm{L}$ of PCR-grade water.

Samples that tested positive for Shigella spp. and Salmonella spp. were further analysed using a m-PCR protocol specifically to detect S. flexneri, Shigella spp., S. typhimurium and S. enteritidis as described previously. ${ }^{[19]}$ Each reaction consisted of 1X Qiagen PCR multiplex mix (containing HotstartTaq DNA polymerase, m-PCR buffer and dNTP mix), $2 \mu \mathrm{L}$ of the primer, $4 \mu \mathrm{L}$ of DNA sample and $4 \mu \mathrm{L}$ of PCR-grade water.

All PCR reactions were conducted using a BIORAD Mcycler thermal cycler. The following PCR conditions were used: initial activation at $95^{\circ} \mathrm{C}$ for 15 mins, followed by 35 cycles that consisted of denaturation at $94^{\circ} \mathrm{C}$ for $45 \mathrm{~s}$, annealing at $55^{\circ} \mathrm{C}$ for $45 \mathrm{~s}$, extension at $68^{\circ} \mathrm{C}$ for 2 mins and elongation at $72^{\circ} \mathrm{C}$ for 5 mins.

All PCR products were analysed using $2.5 \%(\mathrm{w} / \mathrm{v})$ agarose gel containing ethidium bromide $(0.5 \mu \mathrm{g})$ and TAE buffer $(40 \mathrm{mM}$ tris acetate, $2 \mathrm{mM}$ EDTA, $\mathrm{pH}$ 8.3). The DNA was electrophoresed for $1-2 \mathrm{hrs}$ in an electric field strength of $80-100 \mathrm{~V}$, and visualised using UV light (Gene Genius Bio imaging system, Vacutec, Costa Mesa, CA, USA). The relative sizes of the DNA fragments were estimated by comparing their electrophoretic mobility with the standards on each gel using 100 bp markers (Fermentas).

\section{Viral analysis}

Viral pathogens were determined using enzyme immunoassays (EIAs). Enteric adenovirus type 40/41 was detected using Premier Adenoclone 40/41 kit (Meridian Bioscience, Europe), rotavirus using Rotavirus EIA kit (R-Biopharm, Germany) and norovirus using RIDASCREEN Norovirus 3rd Generation EIA kit (R-Biopharm, Germany) according to manufacturers' instructions.

\section{Data analysis}

Data from the EIA and PCR samples were entered into Microsoft Excel (2010) spreadsheets. Data from questionnaires were entered into separate Excel spreadsheets. The average and median of the samples were calculated using Microsoft Excel (2010) when needed.

\section{Results \\ Demographic data of study population}

A total of 237 diarrhoeal stool specimens were collected from children younger than 5 years in primary healthcare facilities. The median age of the study participants was 10 months (range 0 - 60 months). Most of the study participants were age 0 - 12 months $(58.2 \%, n=138)$ and 12 - 24 months $(21.9 \%, n=52)$. Gdender distribution was 122 (51.5\%) male and 105 (44.3\%) female.

\section{Prevalence of enteric pathogens}

At least 1 enteric pathogen was detected in 140 (59.1\%) of the diarrhoeal specimens (Table 1). Single diarrhoeagenic E. coli (DEC) pathotypes, ETEC 7 (3.0\%), EAEC 13 (5.5\%) and atypical EPEC 2 $(0.8 \%)$ were detected. Single viral pathogens detected were rotavirus 9 (3.8\%), norovirus $12(5.1 \%)$ and adenovirus $40 / 416(2.5 \%)$ (Table 1$)$.

Mixed infections of 2 or more bacterial pathogens were detected in 58 (24.5\%); t-EPEC co-infected with ETEC (5.5\%, $n=13)$ and ETEC co-infected with EAEC $(4.2 \%, n=10)$ were the most frequent co-infecting pathogens detected (Table 2). Bacterial and viral co-infections were detected in 34 (14.3\%); EAEC and rotavirus were detected in $10(2.5 \%)$ of the diarrhoeal specimens (Table 2). Fig. 1 indicates single and mixed pathogens on electrophoresis gel using $E$. coli as positive control.

Children under 12 and 24 months were mostly infected with ETEC (34.8\% and $28.8 \%$, respectively) and EAEC (26.0\% and $28.8 \%$, respectively) (Table 3). Overall, 190 of the children under the age of 2 years ( 0 - 24 months) were infected with $\operatorname{EAEC~}(26.8 \%, n=51)$, ETEC $(27.9 \%, n=53)$ and atypical EPEC $(17.9 \%, n=34)$.
Table 1. Prevalence of enteric pathogens in children less than 5 years of age $(N=237)$

\begin{tabular}{ll}
\hline Diarrhoeal pathogen & $\boldsymbol{n}(\%)$ \\
\hline Samples positive & $140(59.1 \%)$ \\
Positive for only one diarrhoeal pathogen & $64(27.0 \%)$ \\
ETEC & $7(3.0 \%)$ \\
EAEC & $13(5.5 \%)$ \\
Atypical EPEC & $2(0.8 \%)$ \\
Typical EPEC & $2(0.8 \%)$ \\
EIEC & $9(3.8 \%)$ \\
Shigella spp. & $2(0.8 \%)$ \\
S. enteritidis & $1(0.4 \%)$ \\
Vibrio spp. & $1(0.4 \%)$ \\
Adenovirus 40/41 & $6(2.5 \%)$ \\
Norovirus & $12(5.1 \%)$ \\
Rotavirus & $9(3.8 \%)$ \\
Bacterial and bacteria co-infections & $58(24.5 \%)$ \\
Bacterial and virus co-infections & $34(14.3 \%)$ \\
Virus and virus co-infections & $2(0.8 \%)$ \\
No pathogen detected & $97(40.1 \%)$ \\
ETEC = enterotoxigenic $E$. coli; EAEC = enteroaggregative E. coli; \\
EPEC = enteropathogenic $E$ coli; EIEC = enteroinvasive E. coli.
\end{tabular}

\section{$\begin{array}{llllllllllllllllllll}1 & 2 & 3 & 4 & 5 & 6 & 7 & 8 & 9 & 10 & 11 & 12 & 13 & 14 & 15 & 16 & 17 & 18 & 19 & 20\end{array}$}

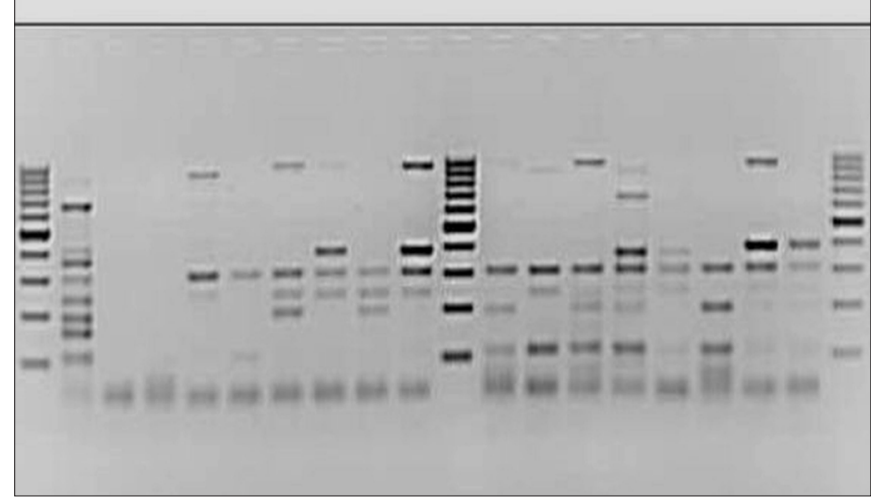

Fig. 1. Agarose gel electrophoresis results for multiplex PCR amplification of diarrhoeagenic E. coli. Lane 1, 11 and 20 molecular weight marker; Lane 2 positive control eae (917 bp), stx2 (779 bp), ial (630 bp), bfp (410 bp), LT (330 bp), Gapdh (238 bp), Eagg (194 bp), ST (160 bp), Asta (106 bp)); Lane 3 negative control; Lane 4 extraction negative; Lane 5 - 10, 12 - 19 samples that tested positive for single and multiple pathogens.

Other bacterial pathogens such as $S$. flexneri $(4.2 \%, n=10), S$. enteritidis $(1.3 \%, n=3)$ and $S$. typhimurium $(0.4 \%, n=1)$ were detected across the age groups. Adenovirus 40/41 was detected in 10 (7.2\%) of the children aged 12 months, 4 (7.7\%) of the children aged 24 months and $4(11.1 \%)$ of the children aged 60 months (Table 3 ).

Of the 48 children infected with t-EPEC, 13 (27.1\%) had diarrhoea only, while $36(75 \%)$ had diarrhoea accompanied by other symptoms such as fever $(25.0 \%, n=12)$, vomiting $(25.0 \%, n=12)$ and dehydration $(6.3 \%, n=3)$ (Table 4). Children infected with ETEC and a-EPEC ( $41.0 \%$ and $48.6 \%$, respectively) had watery stools while those infected with EAEC had formed stools (53.2\%, $n=33$ ) (Table 4).

\section{Discussion}

In this study, the prevalence of enteric pathogens was investigated in children suffering from diarrhoea in rural communities of the Vhembe District, South Africa. The prevalence rate of enteric 
Table 2. Frequency of co-infecting pathogens in children less than 5 years of age $(N=237)$

\begin{tabular}{llll}
\hline Combination of pathogens & $\boldsymbol{n}(\%)$ & Combination of pathogens & $\boldsymbol{n}(\%)$ \\
\hline Bacterial and bacteria co-infections & $58(24.5 \%)$ & Bacterial and virus co-infections & $34(14.3 \%)$ \\
ETEC + typical EPEC & $13(5.5 \%)$ & EAEC + rotavirus & $6(2.5 \%)$ \\
EAEC + ETEC & $10(4.2 \%)$ & EAEC + adenovirus $40 / 41$ & $1(0.4 \%)$ \\
EAEC + typical EPEC & $5(2.1 \%)$ & EAEC + norovirus & $1(0.4 \%)$ \\
ETEC + EHEC & $1(0.4 \%)$ & ETEC + adenovirus $40 / 41$ & $1(0.4 \%)$ \\
ETEC + atypical EPEC & $4(1.7 \%)$ & Shigella spp. + rotavirus & $1(0.4 \%)$ \\
EAEC + atypical EPEC & $1(0.4 \%)$ & atypical EPEC + EIEC + rotavirus & $1(0.4 \%)$ \\
EIEC + typical EPEC & $1(0.4 \%)$ & ETEC + typical EPEC + norovirus & $4(1.7 \%)$ \\
ETEC + S. flexneri & $2(0.8 \%)$ & ETEC + atypical EPEC + rotavirus & $1(0.4 \%)$ \\
EAEC + S. flexneri & $1(0.4 \%)$ & EIEC + rotavirus & $1(0.4 \%)$ \\
Atypical EPEC + S. flexneri & $1(0.4 \%)$ & Typical EPEC + norovirus & $1(0.4 \%)$ \\
S. flexneri + S. enteritidis & $1(0.4 \%)$ & EAEC + atypical EPEC + norovirus & $1(0.4 \%)$ \\
EAEC + ETEC + typical EPEC & $7(3.0 \%)$ & EAEC + atypical EPEC + adenovirus $40 / 41$ & $1(0.4 \%)$ \\
ETEC + t-EPEC + EIEC & $1(0.4 \%)$ & Atypical EPEC + rotavirus + norovirus & $1(0.4 \%)$ \\
EAEC + ETEC + EIEC & $1(0.4 \%)$ & EIEC + rotavirus + adenovirus $40 / 41$ & $1(0.4 \%)$ \\
EAEC + ETEC + atypical EPEC & $4(1.7 \%)$ & EAEC + ETEC + atypical EPEC + norovirus & $2(0.8 \%)$ \\
EAEC+ atypical EPEC + EIEC & $1(0.4 \%)$ & EAEC + ETEC + typical EPEC + adenovirus $40 / 41$ & $3(1.3 \%)$ \\
EAEC+ ETEC + atypical EPEC & $2(0.8 \%)$ & ETEC + atypical EPEC + S. flexneri + rotavirus & $1(0.4 \%)$ \\
EAEC + typical EPEC + S. flexneri & $1(0.4 \%)$ & EAEC + ETEC + EIEC + adenovirus 40/41 & $1(0.4 \%)$ \\
ETEC + typical EPEC + S. flexneri & $1(0.4 \%)$ & EAEC + ETEC + EHEC + norovirus & $1(0.4 \%)$ \\
Virus and virus co-infections & $2(0.8 \%)$ & ETEC + atypical EPEC + adenovirus 40/41 & $1(0.4 \%)$ \\
Rotavirus + norovirus & $1(0.4 \%)$ & ETEC + atypical EPEC + EIEC + norovirus & $1(0.4 \%)$ \\
Rotavirus + adenovirus $40 / 41$ & $1(0.4 \%)$ & EAEC + S. flexneri + adenovirus $40 / 41$ & $1(0.4 \%)$ \\
& & Typical EPEC + S. enteritidis + S. typhimurium + adenovirus & $1(0.4 \%)$
\end{tabular}

$\mathrm{EAEC}=$ enteroaggregative $E$. coli $; \mathrm{ETEC}=$ enterotoxigenic $E$. coli $\mathrm{EHEC}=$ enterohaemorrhagic E. coli $\mathrm{EPEC}=$ enteropathogenic $E$. coli EIEC $=$ enteroinvasive $E$. coli.

Table 3. Distribution of diarrhoea-causing pathogens based on age of population

\begin{tabular}{|c|c|c|c|c|c|}
\hline \multirow[b]{2}{*}{ Pathogen } & \multirow[b]{2}{*}{$\begin{array}{l}\text { All age groups } \\
(N=237)\end{array}$} & \multicolumn{4}{|c|}{ Age group (months) } \\
\hline & & $\begin{array}{l}0-12 \\
(n=138,58 \%)\end{array}$ & $\begin{array}{l}12-24 \\
(n=52,22 \%)\end{array}$ & $\begin{array}{l}24-60 \\
(n=36,15 \%)\end{array}$ & $\begin{array}{l}\text { No data } \\
(n=11,5 \%)\end{array}$ \\
\hline \multicolumn{6}{|l|}{ Bacterial pathogen } \\
\hline EAEC & $62(26.1 \%)$ & $36(26.0 \%)$ & $15(28.8 \%)$ & $9(25.0 \%)$ & $2(18.1 \%)$ \\
\hline Typical EPEC & $48(20.3 \%)$ & $31(22.5 \%)$ & $9(17.3 \%)$ & $8(22.2 \%)$ & $0(0 \%)$ \\
\hline Atypical EPEC & $37(15.6 \%)$ & $25(18.1 \%)$ & $9(17.3 \%)$ & $3(8.3 \%)$ & $0(0 \%)$ \\
\hline ETEC & $73(30.8 \%)$ & $48(34.8 \%)$ & $15(28.8 \%)$ & $9(25.0 \%)$ & $1(9.1 \%)$ \\
\hline EIEC & $18(7.6 \%)$ & $7(5.1 \%)$ & $4(7.7 \%)$ & $7(19.4 \%)$ & $0(0 \%)$ \\
\hline EHEC & $2(0.8 \%)$ & $0(0 \%)$ & $1(1.9 \%)$ & $0(0 \%)$ & $1(9.1 \%)$ \\
\hline S. flexneri & $10(4.2 \%)$ & $4(2.9 \%)$ & $3(5.8 \%)$ & $3(8.3 \%)$ & $0(0 \%)$ \\
\hline Shigella spp. & $3(1.3 \%)$ & $1(0.7 \%)$ & $0(0 \%)$ & $2(5.6 \%)$ & $0(0 \%)$ \\
\hline S. typhimurium & $1(0.4 \%)$ & $0(0 \%)$ & $1(1.9 \%)$ & $0(0 \%)$ & $0(0 \%)$ \\
\hline S. enteritidis & $3(1.3 \%)$ & $2(1.4 \%)$ & $1(1.9 \%)$ & $0(0 \%)$ & $0(0 \%)$ \\
\hline Vibrio spp. & $1(0.4 \%)$ & $1(0.7 \%)$ & $0(0 \%)$ & $0(0 \%)$ & $0(0 \%)$ \\
\hline \multicolumn{6}{|l|}{ Viral pathogen } \\
\hline Adenovirus $40 / 41$ & $18(7.6 \%)$ & $10(7.2 \%)$ & $4(7.7 \%)$ & $4(11.1 \%)$ & $0(0 \%)$ \\
\hline Norovirus & $21(8.9 \%)$ & $11(8.0 \%)$ & $5(9.6 \%)$ & $1(2.7 \%)$ & $4(36.4 \%)$ \\
\hline Rotavirus & $24(10.1 \%)$ & $7(5.1 \%)$ & $9(17.3 \%)$ & $5(13.8 \%)$ & $3(27.2 \%)$ \\
\hline
\end{tabular}

pathogens in this study was $59.1 \%$. Of all the diarrhoeal pathogens detected, diarrhoeagenic E. coli (DEC) pathotypes were more prevalent, with ETEC (30.8\%) and EAEC (26.1\%) being detected at high rates. Other studies have also reported on the prevalence of EAEC in countries such as Mozambique,${ }^{[8]}$ Kenya,${ }^{[10]}$ India, ${ }^{[21]}$ Sudan ${ }^{[9]}$ and Vietnam ${ }^{[7]}$ as a major cause of moderate to severe diarrhoea in 
Table 4. Clinical symptoms of children infected with diarrhoeagenic $E$. coli pathotypes $(N=237)$

\begin{tabular}{|c|c|c|c|c|c|c|}
\hline Properties & $\begin{array}{l}\text { EAEC } \\
(n=62)\end{array}$ & $\begin{array}{l}\text { Atypical EPEC } \\
(n=37)\end{array}$ & $\begin{array}{l}\text { Typical EPEC } \\
(n=48)\end{array}$ & $\begin{array}{l}\text { ETEC } \\
(n=73)\end{array}$ & $\begin{array}{l}\text { EIEC } \\
(n=18)\end{array}$ & $\begin{array}{l}\text { EHEC } \\
(n=2)\end{array}$ \\
\hline \multicolumn{7}{|l|}{ Clinical symptoms } \\
\hline Diarrhoea only & $10(16.1 \%)$ & $18(48.6 \%)$ & $13(27.1 \%)$ & $27(37.0 \%)$ & $5(27.8 \%)$ & $0(0 \%)$ \\
\hline Diarrhoea/other symptoms & $52(83.9 \%)$ & $19(51.4 \%)$ & $36(75.0 \%)$ & $46(63.0 \%)$ & $13(72.2 \%)$ & $2(100 \%)$ \\
\hline Abdominal cramps & $8(12.9 \%)$ & $4(10.8 \%)$ & $9(18.8 \%)$ & $11(15.1 \%)$ & $4(22.2 \%)$ & $1(50 \%)$ \\
\hline Fever $\geq 38^{\circ} \mathrm{C}$ & $16(25.8 \%)$ & $6(16.2 \%)$ & $12(25.0 \%)$ & $17(23.3 \%)$ & $3(16.7 \%)$ & $1(50 \%)$ \\
\hline Vomiting & $19(30.6 \%)$ & $\begin{array}{l}8 \\
(21.6 \%)\end{array}$ & $12(25.0 \%)$ & $13(17.8 \%)$ & $4(22.2 \%)$ & $0(0 \%)$ \\
\hline Dehydration & $9(14.5 \%)$ & $1(2.7 \%)$ & $3(6.3 \%)$ & $5(6.8 \%)$ & $2(11.1 \%)$ & $0(0 \%)$ \\
\hline \multicolumn{7}{|l|}{ Stool type } \\
\hline Watery & $19(30.6 \%)$ & $18(48.6 \%)$ & $20(41.7 \%)$ & $30(41.0 \%)$ & $9(50.0 \%)$ & $1(50 \%)$ \\
\hline Loose/mushy & $10(16.1 \%)$ & $5(13.5 \%)$ & $10(20.8 \%)$ & $13(17.8 \%)$ & $6(33.3 \%)$ & $0(0 \%)$ \\
\hline Formed & $33(53.2 \%)$ & $14(37.8 \%)$ & $19(39.6 \%)$ & $30(41.0 \%)$ & $3(16.7 \%)$ & $1(50 \%)$ \\
\hline
\end{tabular}

children under 2 years. ETEC has been reported to cause diarrhoea in children under 5 years. ${ }^{[8,13,22]}$ EPEC has been recognised as a diarrhoea-causing pathogen in children less than 2 years, ${ }^{[0,14,23]}$ and is reported to cause deaths in infants. ${ }^{[2,24]}$ EPEC is characterised mainly by the presence or absence of the bundle-forming pili $(b f p)$. In the present study, typical EPEC of $20.3 \%$ (with $b f p$ and eae) was higher when compared with atypical EPEC of $15.6 \%$ (no bfp, only eae gene) across all age groups. The Global Multicenter Study (GEMS) which focused on major countries located in Asia and sub-Saharan Africa also reported ETEC, typical EPEC, rotavirus and Shigella as some of the major causes of moderate to severe diarrhoea in children under the age of 2 years. ${ }^{[2]}$

Enteric viruses such as rotavirus were detected in $10.1 \%$ of samples as compared with other studies, ${ }^{[25-28]}$ which could mainly be due to the introduction of the rotavirus vaccine in South Africa. ${ }^{[29]}$ Adenovirus 40/41 and norovirus were detected in low frequencies across all age groups. Other studies have reported these viruses cause diarrhoea in children, especially under the age of 5 years. [23,26,28,30] The low detection rate of viruses has led to children, especially those under 2 years of age, to be susceptible to other enteric pathogens as seen in this study. One of the limitations in this study due to financial constraints, was the use of EIAs for detection of enteric viruses instead of PCR. As PCR is more sensitive than EIA, commercially available EIA cannot detect certain types of viral recombinant genes ${ }^{[31]}$ and, as a result, enteric viruses were detected in a limited number of samples. Another limitation was that demographic and clinical data of study participants were not consistently collected by some of the professional nurses as some of the data were missing.

\section{Conclusion}

Children living in rural settings of the Vhembe District have been previously reported to be infected with diarrhoeal pathogens such as norovirus, ${ }^{[18]}$ rotavirus, ${ }^{[5,17]}$ EAEC,${ }^{[4,15]}$ ETEC, EPEC ${ }^{[4]}$ Shigella spp. and Salmonella spp. ${ }^{[5]}$ In the present study, children under the age of 24 months were found to be more susceptible to enteric infections, with an occurrence of 2 or more pathogens detected in most of the study participants. DEC pathotypes occurred frequently in mixed infections with other bacterial and viral pathogens. There are several studies that have reported on the occurrence of co-infecting pathogens in children ${ }^{[12,16,30,32]}$ The most frequent DEC co-infection was ETEC and typical EPEC in 5.5\% of the episodes. Crane et al. ${ }^{[33]}$ studied the interaction of EPEC and ETEC in vitro and found that ETEC virulence genes were significantly increased when co-infected with EPEC.

The high detection rate of DEC pathotypes, especially in co-infections, raises serious health concerns for the well-being of young children. Further studies are therefore needed to determine the interaction of DEC pathotypes and the role that these pathogens play in severity of disease during co-infections, as this has not been well defined. Clinical symptoms of all the DEC infections were almost similar, and most cases of diarrhoea were accompanied by other symptoms such as abdominal pain, vomiting, fever and dehydration. In conclusion, enteric pathogens are important aetiological agents of diarrhoea in children. DEC infections were more prevalent, posing a health risk to children less than 2 years of age in rural communities of the Vhembe District of Limpopo Province, South Africa.

Acknowledgements. The authors would like to acknowledge all the nurses at the primary healthcare facilities in the study area who assisted in the collection of stool samples.

Author contributions. NP was the project leader and supervisor of SEL. ANT was co-supervisor and mentor. JPK and SEL collected samples. SEL and TGB did the molecular analyses. SEL did the ELISA analysis and concept manuscript. All authors contributed to the writing and approval of the manuscript.

Funding. This work was funded by the Water Research Commission (WRC) of South Africa (grant number K3/1750), the National Research Foundation (NRF), and the Research and Innovation Directorate of the University of Venda (registration number SMNS/14/MBY/28).

Conflicts of interest. None. 
1. Liu L, Oza S, Hogan D, et al. Global, regional, and national causes of child mortality in 2000-13, with projections to inform post-2015 priorities: An updated systematic analysis. Lancet 2015;385(9966):430-440. https://doi. org/10.1016/S0140-6736(14)61698-6

2. Kotloff KL, Nataro JP, Blackwelder WC, et al. Burden and aetiology of diarrhoeal disease in infants and young children in developing countries (the Global Enteric Multicenter Study, GEMS): A prospective, case-control study. Lancet 2013;382(9888):209-222. https://doi.org/10.1016/S0140-6736(13)60844-2

3. Traoré AN, Mulaudzi K, Chari GJ, et al. The impact of human activities on microbial quality of rivers in the Vhembe District, South Africa. Int J Environ Res Public Health 2016;13(8):817. https://doi.org/10.3390/ijerph13080817

4. Obi CL, Green E, Bessong PO, et al. Gene encoding virulence markers among Escherichia coli isolates from diarrhoeic stool samples and river sources in rura Venda communities of South Africa. Water SA 2004;30(1):37-42. https://doi. org/10.4314/wsa.v30i1.5024

5. Obi CL, Potgieter N, Bessong PO, Igumbor EO, Green E. Prevalence of pathogenic bacteria and rotaviruses in stools of patients presenting with diarrhoea from rura communities in Venda, South Africa. S Afr J Sci 2003;99(11-12):589-592.

6. Youssef M, Shurman A, Bougnoux ME, Rawashdeh M, Bretagne S, Strockbine N. Bacterial, viral and parasitic enteric pathogens associated with acute diarrhea in hospitalized children from northern Jordan. Pathog Dis 2000;28(3):257-263.

7. Nguyen TV, Le Van P, Le Huy C, Gia KN, Weintraub A. Detection and characterization of diarrheagenic Escherichia coli from young children in Hanoi, Vietnam. J Clin Microbiol 2005;43(2):755-760. https://doi.org/10.1128/ JCM.43.2.755-760.2005

8. Nhampossa T, Mandomando I, Acacio S, et al. Diarrheal disease in rural Mozambique: Burden, risk factors and etiology of diarrheal disease among children aged 0 - 59 months seeking care at health facilities. PLoS One 2015;10(5):e0119824. https://doi.org/10.1371/journal.pone.0119824

9. Saeed A, Abd H, Sandstrom G. Microbial aetiology of acute diarrhoea in children under five years of age in Khartoum, Sudan. J Med Microbiol 2015;64(4):432-437. https://doi.org/10.1099/jmm.0.000043

10. Shah M, Kathiiko C, Wada A, et al. Prevalence, seasonal variation, and antibiotic resistance pattern of enteric bacterial pathogens among hospitalized diarrheic children in suburban regions of central Kenya. Trop Med Health 2016;44(1):39. https://doi.org/10.1186/s41182-016-0038-1

11. Iijima Y, Oundo JO, Hibino T, et al. High prevalence of diarrheagenic Escherichia coli among children with diarrhea in Kenya. Jpn J Infect Dis 2017;70(1):80-83. https://doi.org/10.7883/yoken.JJID.2016.064

12. Vilchez S, Reyes D, Paniagua M, Bucardo F, Möllby R, Weintraub A. Prevalence of diarrhoeagenic Escherichia coli in children from León, Nicaragua. J Med Microbiol 2009;58(5):630-637. https://doi.org/10.1099/jmm.0.007369-0

13. Kabayiza JC, Andersson ME, Nilsson S, et al. Diarrhoeagenic microbes by realtime PCR in Rwandan children under 5 years of age with acute gastroenteritis Clin Microbiol Infect 2014;20(12):1128-1135. https://doi.org/10.1111/14690691.12698

14. Nitiema LW, Nordgren J, Ouermi D, et al Burden of rotavirus and other enteropathogens among children with diarrhea in Burkina Faso. Int J Infect Dis 2011;15(9):e646-652. https://doi.org/10.1016/j.ijid.2011.05.009

15. Samie A, Obi CL, Dillingham R, Pinkerton RC, Guerrant RL. Enteroaggregative Escherichia coli in Venda, South Africa: Distribution of virulence-related genes by multiplex polymerase chain reaction in stool samples of human immunodeficiency virus (HIV)-positive and HIV-negative individuals and primary school children. Am J Trop Med Hyg 2007;77(1):142-150.

16. Samie A, Guerrant RL, Barrett L, Bessong PO, Igumbor EO, Obi CL. Prevalence of intestinal parasitic and bacterial pathogens in diarrhoeal and non-diarroeal human stools from Vhembe district, South Africa. J Heal Popul Nutr 2009;27(6):739-745.

17. Potgieter N, De Beer MC, Taylor MB, Steele AD. Prevalence and diversity of rotavirus strains in children with acute diarrhea from rural communities in the Limpopo Province, South Africa, from 1998 to 2000. J Infect Dis 2010;202(Suppl 1):S148-155. https://doi.org/10.1086/653561
18. Kabue JP, Meader E, Hunter PR, Potgieter N. Norovirus prevalence and estimated viral load in symptomatic and asymptomatic children from rural communities of Vhembe district, South Africa. J Clin Virol 2016;84:12-18. https://doi. org/10.1016/j.jcv.2016.09.005

19. Mieta SIK, Potgieter N, Sobsey MD, Barnard TG. Optimisation of methods for the collection and detection of bacterial pathogens from diarrhoeal human faecal samples using a novel stool collection kit. Water SA 2010;36(2):159-166.

20. Omar KB, Barnard TG. Detection of diarrhoeagenic Escherichia coli in clinical and environmental water sources in South Africa using single-step 11-gene m-PCR. World J Microbiol Biotechnol 2014;30(10):2663-2671. https://dx.doi. org/10.1007\%2Fs11274-014-1690-4

21. Shrivastava AK, Kumar S, Mohakud NK, Suar M, Sahu PS. Multiple etiologies of infectious diarrhea and concurrent infections in a pediatric outpatient based screening study in Odisha, India. Gut Pathog 2017;9(1):16. https://doi. org/10.1186/s13099-017-0166-0

22. Trainor E, Iturriza-Gómara M, Ngwira B, Cunliffe $N$. Detection of enterotoxigenic E. coli in hospitalised children with and without diarrhoea in Blantyre, Malawi. Paediatr Int Child Health 2016;36(2):102-105. https://doi.org /10.1179/2046905515Y.0000000014

23. Bodhidatta L, McDaniel P, Sornsakrin S, Srijan A, Serichantalergs O, Mason CJ. Case-control study of diarrheal disease etiology in a remote rural area in Western Thailand. Am J Trop Med Hyg 2010;83(5):1106-1109. https://doi org/10.4269/aitmh.2010.10-0367

24. Platts-Mills JA, Babji S, Bodhidatta L, et al. Pathogen-specific burdens of community diarrhoea in developing countries: A multisite birth cohort study (MAL-ED). Lancet Glob Health 2015;3(9):e564-575. https://doi.org/10.1016/ S2214-109X(15)00151-5

25. Mans J, de Villiers JC, du Plessis NM, Avenant T, Taylor MB. Emerging norovirus GII.4 2008 variant detected in hospitalised paediatric patients in South Africa. J Clin Virol 2010;49(4):258-264. https://doi.org/10.1016/j.jcv.2010.08.011

26. Lekana-Douki SE, Kombila-Koumavor C, Nkoghe D, Drosten C, Drexler JF Leroy EM. Molecular epidemiology of enteric viruses and genotyping of rotavirus A, adenovirus and astrovirus among children under 5 years old in Gabon. Int J Infect Dis 2015;34:90-95. https://doi.org/10.1016/j.ijid.2015.03.009

27. Borrows CL, Turner PC. Seasonal screening for viral gastroenteritis in young children and elderly hospitalized patients : Is it worthwhile? J Hosp Infect 2014;87(2):98-102. https://doi.org/10.1016/j.jhin.2014.02.011

28. Moyo SJ, Maselle SY, Matee MI, Langeland N, Mylvaganam H. Identification of diarrheagenic Escherichia coli isolated from infants and children in Dar es Salaam, Tanzania. BMC Infect Dis 2007;7(1):92. https://doi.org/10.1186/1471 2334-7-92

29. Groome MJ, Page N, Cortese MM, et al. Effectiveness of monovalent human rotavirus vaccine against admission to hospital for acute rotavirus diarrhoea in South African children: A case-control study. Lancet Infect Dis 2014;14(11):1096-1104. https://doi.org/10.1016/S1473-3099(14)70940-5

30. Stockmann C, Pavia AT, Graham B, et al. Detection of 23 gastrointestina pathogens among children who present with diarrhea. J Pediatric Infect Dis Soc 2016;6(3):231-238. https://doi.org/10.1093/jpids/piw020

31. Kele B, Lengyel G, Deak J. Comparison of an ELISA and two reverse transcription polymerase chain reaction methods for norovirus detection. Diag Microbiol Infect Dis 2011;70(4):475-478. https://doi.org/10.1016/j. diagmicrobio.2011.04.002

32. Soli KW, Maure T, Kas MP, et al. Detection of enteric viral and bacteria pathogens associated with paediatric diarrhoea in Goroka, Papua New Guinea. Int J Infect Dis 2014;27:54-58. https://doi.org/10.1016/j.ijid.2014.02.023

33. Crane JK, Choudhari SS, Naeher TM, Duffey ME. Mutual enhancement of virulence by enterotoxigenic and enteropathogenic Escherichia coli. Infect Immun 2006;74(3):1505-1515. https://doi.org/10.1128/IAI.74.3.1505-1515.2006

Accepted 11 June 2018. 